\title{
Method Development and Validation for Simultaneous Estimation of Ethinyl Estradiol and Drospirenone and Forced Degradation Behavior by HPLC in Combined Dosage Form
}

Praveen $C^{*}$, Ranganath MK and Divakar $\mathbf{P}$

Department of Pharmaceutical Analysis, Krupanidhi College of Pharmacy, Bangalore, India

\begin{abstract}
A simple, accurate, rapid and precise isocratic High performance liquid chromatographic (HPLC) method was developed and validated for the determination of ethinyl estradiol and drospirenone in tablet formulation. The method employs Waters HPLC system on Thermo Hypersil BDS C18 Column $(4.6 \times 250 \mathrm{~mm}$ and $5 \mu \mathrm{m})$ and flow rate of 1.0 $\mathrm{ml} / \mathrm{min}$ with a load of $15 \mu \mathrm{l}$. Acetonitrile and ammonium acetate buffer was used as mobile phase in the composition of $30: 70$. The detection was carried out at $258 \mathrm{~nm}$. Linearity ranges for ethinyl estradiol and drospirenone were $0.06-$ $0.18 \mu \mathrm{g} / \mathrm{ml}, 6-18 \mu \mathrm{g} / \mathrm{ml}$ respectively. Retention Time of ethinyl estradiol and drospirenone were found to be $1.4 \mathrm{~min}$ $5.3 \mathrm{~min}$ respectively. Percent Recovery study values of ethinyl estradiol and drospirenone were found to be within $97-103 \%$. The combination product is exposed to acid/base, hydrolytic, photolytic and peroxide stress conditions and the stressed samples were analyzed. This developed method was successfully utilized for the quantitative estimation of ethinyl estradiol and drospirenone in pharmaceutical dosage forms. This method was validated for accuracy, precision, linearity and Robustness as per ICH guidelines.
\end{abstract}

Keywords: Ethinyl estradiol; Drospirenone; RP HPLC; Forced degradation

\section{Introduction}

Ethinyl estradiol is also known as ethynyl estradiol (EE) which is a derivative of $17 \beta$ - estradiol. It is the first orally active semi synthetic steroidal estrogen that is used for the management of menopausal symptoms and female hypogonadism. Ethinyl estradiol is an orally bioactive estrogen used in almost all modern formulations of combined oral contraceptive pills. Chemically it is 19 -Nor-17a-pregna-1, 3, 5(10)-trien-20-yne-3, 17-diol.

Drospirenone is an analogue of the antimineralocorticoid spironolactone that is synthesized from androstenone. Unlike other progestogens, drospirenone, an analogue of spironolactone, has biochemical and pharmacologic profiles similar to endogenous progesterone, especially regarding antimineralocorticoid and antiandrogenic activities. As a combination, oral contraceptive, drospirenone with ethinyl estradiol, is effective and has positive effects on weight and lipid levels (Figures 1 and 2) [1,2].

Earlier publications have described spectroscopic and chromatographic methods for the quantification of ethinyl estradiol and drospirenone individually. A high-performance liquid chromatography (HPLC) methodology useful for the quantification of drospirenone in tablet dosage form was reported [3].

So far to our present knowledge, HPLC methods were available in the literature for analyzing ethinyl estradiol and drospirenone with other drug combinations in pharmaceutical dosage forms [4,5]. It felt necessary to develop a simple, precise and rapid spectrophotometric method for the quantitative determination of ethinyl estradiol and drospirenone in combined dosage form.

Forced degradation studies were used in the development of this methodology as a stability indicating parameter. The devised method was found to be selective, reliable, faster and straight forward than other reported methods. Though no attempt was made to identify the degradation products, described method can be used as stability indicating method for the assay of ETH and DRO in their combined dosage form.

\section{Materials and Methods}

Apparatus / Instruments used

\begin{tabular}{|c|c|c|c|}
\hline S.No & Name & Model & Manufacturer \\
\hline 1 & HPLC & 2695 & Waters \\
\hline 2 & Detector (PDA) & 2998 & Waters \\
\hline 3 & $\begin{array}{c}\text { UV-VIS Double Beam } \\
\text { Spectrophotometer }\end{array}$ & 3200 & Labindia \\
\hline 4 & Sonicator & - & Labindia \\
\hline 5 & Weighing balance & Bsa224s-cw & Sartorius \\
\hline
\end{tabular}

\begin{tabular}{|c|c|c|c|}
\hline S.No & Name & Grade & Manufacturer \\
\hline 1 & Ammonium acetate & - & Fisher Scientific \\
\hline 2 & Acetonitrile & HPLC & Merk \\
\hline 3 & Methanol & HPLC & Merk \\
\hline & & HPLC Double & Milli-QRO \\
\hline 4 & Double distilled Water & & \\
\hline & & distilled & purification system \\
\hline
\end{tabular}

*Corresponding author: Praveen C, Department of Pharmaceutical Analysis Krupanidhi College of Pharmacy, Bangalore, India, Tel: +91-959-103-1033; E-mail: cpraveen122@gmail.com

Received April 01, 2013; Accepted April 23, 2013; Published April 25, 2013

Citation: Praveen C, Ranganath MK, Divakar P (2013) Method Development and Validation for Simultaneous Estimation of Ethinyl Estradiol and Drospirenone and Forced Degradation Behavior by HPLC in Combined Dosage Form. Pharmaceut Anal Acta 4: 231. doi:10.4172/2153-2435.1000231

Copyright: (c) 2013 Praveen C, et al. This is an open-access article distributed under the terms of the Creative Commons Attribution License, which permits unrestricted use, distribution, and reproduction in any medium, provided the original author and source are credited. 
Citation: Praveen C, Ranganath MK, Divakar P (2013) Method Development and Validation for Simultaneous Estimation of Ethinyl Estradiol and Drospirenone and Forced Degradation Behavior by HPLC in Combined Dosage Form. Pharmaceut Anal Acta 4: 231. doi:10.4172/21532435.1000231

Page 2 of 5

\section{Working standards}

Pharmaceutical grade ethinyl estradiol and drospirenone were kindly supplied as a gift sample by Lara Drugs Private Limited, Hyderabad, Andhra Pradesh, India.

\section{Method development}

Preparation of mobile phase: The mobile phase was prepared by mixing ammonium acetate: acetonitrile in the ratio of (70:30) and was filtered and degassed.

Preparation of standard drug solutions: Accurately weigh and transfer $24 \mathrm{mg}$ drospirenone and $0.24 \mathrm{mg}$ ethinyl estradiol into a $50 \mathrm{ml}$ volumetric flask. Add about $30 \mathrm{ml}$ of methanol and sonicate to dissolve it completely and make volume up to the mark with the same solvent (stock solution). Further pipette out $5 \mathrm{ml}$ of stock solution into a 10 $\mathrm{ml}$ volumetric flask and dilute up to the mark with methanol to get a solution of drospirenone $(0.12 \mathrm{mcg} / \mathrm{ml})$ and ethinyl estradiol $(0.0012$ $\mathrm{mcg} / \mathrm{ml})$.

Accurately weigh about $24 \mathrm{mg}$ of the drospirenone and transfer into a $50 \mathrm{ml}$ clean, dry standard volumetric flask, add $25 \mathrm{ml}$ of methanol, sonicate for 30 minutes and make up with methanol (stock solution). Further pipette out $5 \mathrm{ml}$ of stock solution into a $10 \mathrm{ml}$ volumetric flask and dilute up to the mark with methanol to get a solution of drospirenone $(0.12 \mathrm{mcg} / \mathrm{ml})$.

Accurately weigh about $0.24 \mathrm{mg}$ of the ethinyl estradiol and transfer into a $50 \mathrm{ml}$ clean, dry standard volumetric flask, add $25 \mathrm{ml}$ of methanol, Sonicate for 30 minutes and make up with methanol

\begin{tabular}{|c|c|c|c|c|c|c|}
\hline & \multicolumn{3}{|c|}{ Ethinyl estradiol } & \multicolumn{3}{c|}{ Drospirenone } \\
\hline Parameters & RT & USP Tailing & $\begin{array}{c}\text { USP Plate } \\
\text { Count }\end{array}$ & RT & $\begin{array}{c}\text { USP } \\
\text { Tailing }\end{array}$ & $\begin{array}{c}\text { USP Plate } \\
\text { Count }\end{array}$ \\
\hline FLOW1 & 1.805 & 1.706 & 3598 & 6.392 & 1.202 & 8468 \\
\hline FLOW2 & 1.209 & 1.750 & 3540 & 4.367 & 1.162 & 7074 \\
\hline TEMP1 & 1.450 & 1.704 & 3607 & 5.236 & 1.186 & 7752 \\
\hline TEMP2 & 1.447 & 1.753 & 3590 & 5.160 & 1.173 & 7891 \\
\hline
\end{tabular}

Table 1: Robustness results for ethinyl estradiol and drospirenone.

\begin{tabular}{|c|c|c|c|c|}
\hline \multicolumn{3}{|c|}{ Ethinyl estradiol } & \multicolumn{2}{c|}{ Drospirenone } \\
\hline Sample Name & RT & Area & RT & Area \\
\hline ACID & 1.452 & 2125132 & 5.188 & 1507952 \\
\hline BASE & 1.450 & 2266435 & 5.183 & 1591152 \\
\hline PEROXIDE & 1.454 & 2263747 & 5.192 & 1578856 \\
\hline WATER & 1.455 & 2227253 & 5.194 & 1545941 \\
\hline LIGHT & 1.456 & 2281245 & 5.195 & 1583567 \\
\hline Mean & & 2232762 & & 1561493 \\
\hline SD & & 63362 & & 34558 \\
\hline \%RSD & & 2.8 & & 2.2 \\
\hline
\end{tabular}

Table 2: Results of forced degradation studies.

\begin{tabular}{|c|c|c|c|}
\hline Drug & Conc. $(\boldsymbol{\mu g} / \mathbf{m l})$ & Equation of regression line & $\mathbf{R}^{\mathbf{2}}$ \\
\hline ETH & $0.06-0.18$ & $\mathrm{Y}=29020 \mathrm{x}+42584$ & 0.998 \\
\hline DRO & $6-18$ & $\mathrm{Y}=20634 \mathrm{x}+13023$ & 0.999 \\
\hline
\end{tabular}

Table 3: Linearity results for ethinyl estradiol and drospirenone.

\begin{tabular}{|c|c|c|}
\hline Drug & \%RSD (intra-day) & \%RSD (inter-day) \\
\hline ETH & 0.717 & 0.91 \\
\hline DRO & 1.414 & 0.57 \\
\hline
\end{tabular}

Table 4: Precision results for ethinyl estradiol and drospirenone.

\begin{tabular}{|c|c|c|c|c|c|c|}
\hline \multicolumn{7}{|c|}{ ETHINYL ESTRADIOL } \\
\hline $\begin{array}{c}\text { Spiked } \\
\text { Level }\end{array}$ & $\begin{array}{l}\text { Sample } \\
\text { Weight }\end{array}$ & $\begin{array}{c}\text { Sample } \\
\text { Area }\end{array}$ & $\begin{array}{c}\mathrm{mcg} / \mathrm{ml} \\
\text { added }\end{array}$ & $\begin{array}{l}\mathrm{mcg} / \mathrm{ml} \\
\text { found }\end{array}$ & $\begin{array}{c}\% \\
\text { Recovery }\end{array}$ & $\begin{array}{c}\% \\
\text { Mean }\end{array}$ \\
\hline $50 \%$ & 625.40 & 1484085 & 0.059 & 0.06 & 101 & \multirow{6}{*}{101} \\
\hline $50 \%$ & 625.40 & 1476424 & 0.059 & 0.06 & 100 & \\
\hline $50 \%$ & 625.40 & 1462429 & 0.059 & 0.06 & 99 & \\
\hline $50 \%$ & 625.40 & 1489768 & 0.059 & 0.06 & 101 & \\
\hline $50 \%$ & 625.40 & 1490425 & 0.059 & 0.06 & 101 & \\
\hline $50 \%$ & 625.40 & 1483474 & 0.059 & 0.06 & 101 & \\
\hline $100 \%$ & 1250.80 & 2943921 & 0.119 & 0.12 & 100 & \multirow{3}{*}{100} \\
\hline $100 \%$ & 1250.80 & 2915651 & 0.119 & 0.12 & 99 & \\
\hline $100 \%$ & 1250.80 & 2957407 & 0.119 & 0.12 & 100 & \\
\hline $150 \%$ & 1876.20 & 4423964 & 0.178 & 0.18 & 100 & \multirow{6}{*}{99} \\
\hline $150 \%$ & 1876.20 & 4409785 & 0.178 & 0.18 & 100 & \\
\hline $150 \%$ & 1876.20 & 4420727 & 0.178 & 0.18 & 100 & \\
\hline $150 \%$ & 1876.20 & 4302456 & 0.178 & 0.17 & 97 & \\
\hline $150 \%$ & 1876.20 & 4427862 & 0.178 & 0.18 & 100 & \\
\hline $150 \%$ & 1876.20 & 4338740 & 0.178 & 0.18 & 98 & \\
\hline
\end{tabular}

Table 5: Accuracy results for ethinyl estradiol.

(stock solution). Further pipette out $5 \mathrm{ml}$ of stock solution into a 10 $\mathrm{ml}$ volumetric flask and dilute up to the mark with methanol to get a solution of ethinyl estradiol $(0.0012 \mathrm{mcg} / \mathrm{ml})$.

Preparation of sample drug solution: Transfer $1250.8 \mathrm{mg}(10$ tablets) of marketed sample into a $50 \mathrm{ml}$ of volumetric flask, add 25 $\mathrm{ml}$ of methanol, sonicate it for 10 minutes and make up with methanol (stock solution). Transfer $10 \mathrm{ml}$ of stock solution into $50 \mathrm{ml}$ of volumetric flask dilute to volume with methanol.

Chromatographic Run: Standard solution containing a mixture of drospirenone and ethinyl estradiol was loaded into the injector and HPLC parameters were entered as per table 7 . This method was saved and then sample was injected and run for $7 \mathrm{~min}$.

\section{Chromatographic conditions for the optimized method}

\begin{tabular}{|c|c|}
\hline Parameters & Description \\
\hline Column & C18 Thermo Hypersil BDS $(250 \times 4.6 \times 5 \mathrm{~mm})$ \\
\hline Mobile phase & Ammonium acetate : Acetonitrile $(70: 30)$ \\
\hline Injection volume & $15 \mu \mathrm{l}$ \\
\hline Flow rate & $1 \mathrm{ml} / \mathrm{min}$ \\
\hline Detector Wavelength & PDA at $258 \mathrm{~nm}$ \\
\hline $\begin{array}{c}\text { Column Temperature } \\
\text { Auto Sampler } \\
\text { Temperature }\end{array}$ & $40^{\circ} \mathrm{C}$ \\
\hline Run Time & $25^{\circ} \mathrm{C}$ \\
\hline
\end{tabular}

\section{Results and Discussion}

\section{Validation}

The method was validated for accuracy, precision, linearity, limit of detection, limit of quantitation and robustness as per ICH guidelines (Figures 3 and 4).

\section{Specificity and selectivity}

It is the extent to which the procedure applies to analyte of interest and is checked by examining the formulation samples for any interfering peaks. The specificity of the method was evaluated with regard to interference due to presence of blank and any other excipients. The figure shows that drug was clearly separated from blank 
Citation: Praveen C, Ranganath MK, Divakar P (2013) Method Development and Validation for Simultaneous Estimation of Ethinyl Estradiol and Drospirenone and Forced Degradation Behavior by HPLC in Combined Dosage Form. Pharmaceut Anal Acta 4: 231. doi:10.4172/21532435.1000231

and its excipients. Figure 2 shows chromatogram for the formulation show that the selected drugs were clearly separated. Thus the proposed HPLC method is selective.

Forced Degradation studies of the drug product were carried out under stress conditions. The drug product in solution state was conducted with $0.1 \mathrm{~N} \mathrm{HCl}$ for $30 \mathrm{~min}$. Base hydrolysis of drug product was conducted by $0.1 \mathrm{~N} \mathrm{NaOH}$ for $30 \mathrm{~min}$. For oxidative stress, sample solutions of drug product in $3 \%$ hydrogen peroxide were kept (Tables 1 and 2).

\section{Linearity}

The linearity of the method was determined at five concentration levels ranging from $0.06-0.18 \mu \mathrm{g} / \mathrm{ml}$ for ethinyl estradiol and $6-18$ $\mu \mathrm{g} / \mathrm{ml}$ for drospirenone. The regression equation of calibration curves

\begin{tabular}{|c|c|c|c|c|c|c|}
\hline \multicolumn{7}{|c|}{ DROSPIRENONE } \\
\hline $\begin{array}{c}\text { Spiked } \\
\text { Level }\end{array}$ & $\begin{array}{l}\text { Sample } \\
\text { Weight }\end{array}$ & $\begin{array}{c}\text { Sample } \\
\text { Area }\end{array}$ & $\begin{array}{c}\mathrm{mcg} / \mathrm{ml} \\
\text { added }\end{array}$ & $\begin{array}{l}\mathrm{mcg} / \mathrm{ml} \\
\text { found }\end{array}$ & $\%$ Recovery & $\%$ Mean \\
\hline $50 \%$ & 625.40 & 1000737 & 6.056 & 5.96 & 98 & \multirow[b]{6}{*}{98} \\
\hline $50 \%$ & 625.40 & 997394 & 6.056 & 5.94 & 98 & \\
\hline $50 \%$ & 625.40 & 987911 & 6.056 & 5.89 & 97 & \\
\hline $50 \%$ & 625.40 & 1001888 & 6.056 & 5.97 & 99 & \\
\hline $50 \%$ & 625.40 & 1007424 & 6.056 & 6.00 & 99 & \\
\hline $50 \%$ & 625.40 & 1006174 & 6.056 & 6.00 & 99 & \\
\hline $100 \%$ & 1250.80 & 2045007 & 12.120 & 12.19 & 101 & \multirow[b]{3}{*}{101} \\
\hline $100 \%$ & 1250.80 & 2034841 & 12.120 & 12.13 & 100 & \\
\hline $100 \%$ & 1250.80 & 2064497 & 12.120 & 12.30 & 102 & \\
\hline $150 \%$ & 1876.20 & 3087552 & 18.178 & 18.40 & 101 & \multirow[b]{6}{*}{102} \\
\hline $150 \%$ & 1876.20 & 3086164 & 18.178 & 18.39 & 101 & \\
\hline $150 \%$ & 1876.20 & 3100722 & 18.178 & 18.48 & 102 & \\
\hline $150 \%$ & 1876.20 & 3112915 & 18.178 & 18.55 & 102 & \\
\hline $150 \%$ & 1876.20 & 3122673 & 18.178 & 18.61 & 102 & \\
\hline $150 \%$ & 1876.20 & 3130111 & 0.178 & 18.65 & 103 & \\
\hline
\end{tabular}

Table 6: Accuracy results for Drospirenone.

\begin{tabular}{|l|l|l|}
\hline Validation Parameters & Ethinyl estradiol & Drospirenone \\
\hline Mobile Phase & $\begin{array}{l}70: 30(\text { Ammonium } \\
\text { Acetate: } \mathrm{ACN})\end{array}$ & $\begin{array}{l}70: 30(\text { Ammonium } \\
\text { Acetate: } \mathrm{ACN})\end{array}$ \\
\hline Flow Rate & $1 \mathrm{ml} / \mathrm{min}$ & $1 \mathrm{ml} / \mathrm{min}$ \\
\hline Detection wave Length & PDA at $258 \mathrm{~nm}$ & PDA at $258 \mathrm{~nm}$ \\
\hline Rt & 1.438 & 5.321 \\
\hline Run Time & $7 \mathrm{~min}$ & $7 \mathrm{~min}$ \\
\hline Asymmetry & 1.693 & 1.188 \\
\hline Theoretical Plates & 3636 & 7728 \\
\hline LOD & $0.00026 \mathrm{ppm}$ & $0.0925 \mathrm{ppm}$ \\
\hline LOQ & $0.00087 \mathrm{ppm}$ & $0.308 \mathrm{ppm}$ \\
\hline Linearity & $\mathrm{R}^{2}=0.998$ & $\mathrm{R}^{2}=0.999$ \\
\hline Precision & $\% \mathrm{RSD}<2$ & $\% \mathrm{RSD}<2$ \\
\hline Recovery & $99-101 \%$ & $98-102 \%$ \\
\hline & &
\end{tabular}

Table 7: System suitability parameters for HPLC.

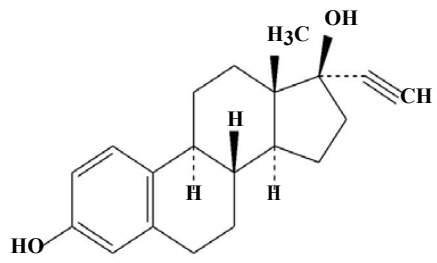

Figure 1: Ethinyl estradiol.

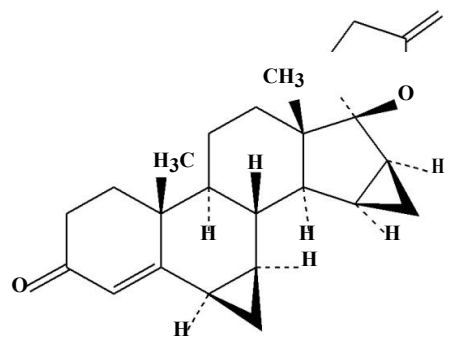

Figure 2: Drospirenone.

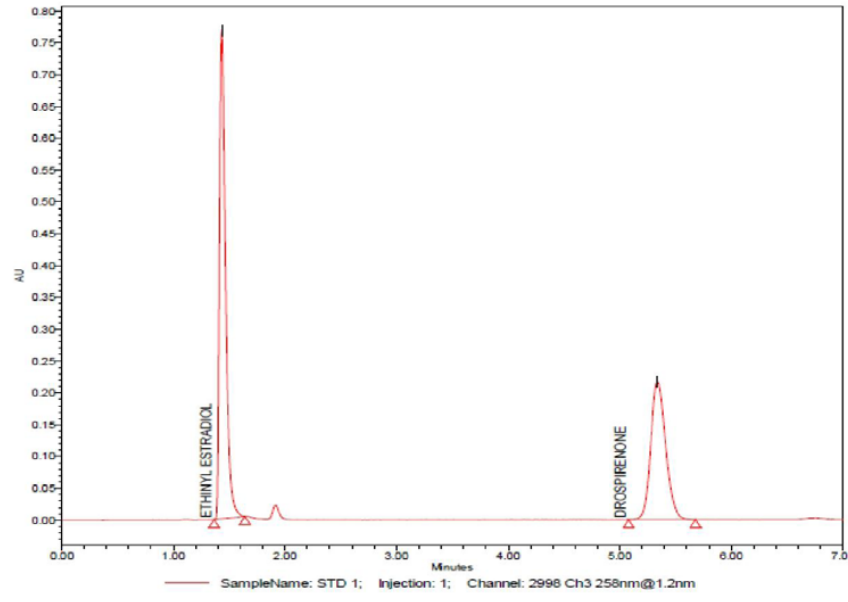

Figure 3: Chromatogram of standard solution of ethinyl estradiol and Drospirenone.

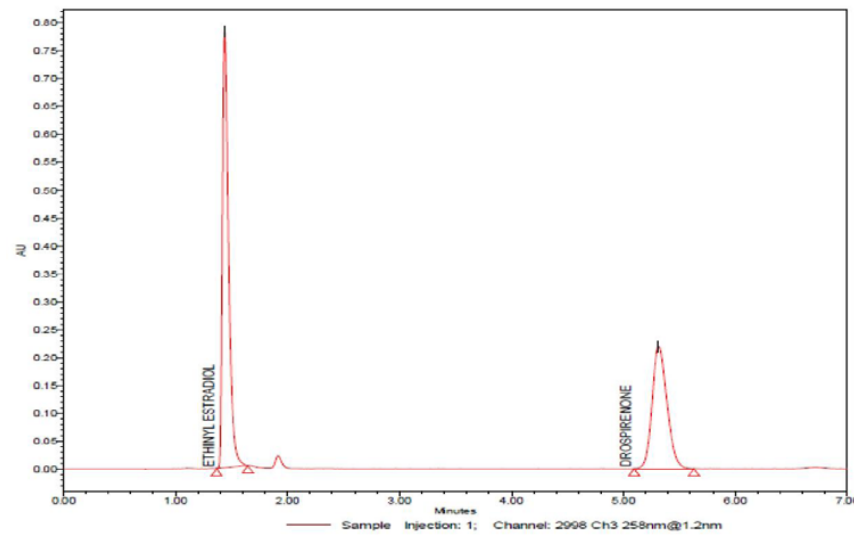

Figure 4: Chromatogram of DROSTAL ${ }^{\mathrm{TM}}$ (Tablet Formulation).

(Figures 3 and 6) were $\mathrm{Y}=29020 \mathrm{x}+42584$ for ethinyl estradiol and $\mathrm{Y}=20634 \mathrm{x}+13023$ for drospirenone and are summarized in table 3, Figures 5 and 6 .

\section{Precision}

Precision of the method was studied as repeatability, intra-day and inter day variations. The intra-day precision was determined by analyzing ETH and DRO six times each on same day (intra-day study). This was repeated on the second day (inter-day study) and the results were shown in table 4, figures 7-10. 
Citation: Praveen C, Ranganath MK, Divakar P (2013) Method Development and Validation for Simultaneous Estimation of Ethinyl Estradiol and Drospirenone and Forced Degradation Behavior by HPLC in Combined Dosage Form. Pharmaceut Anal Acta 4: 231. doi:10.4172/21532435.1000231

Page 4 of 5

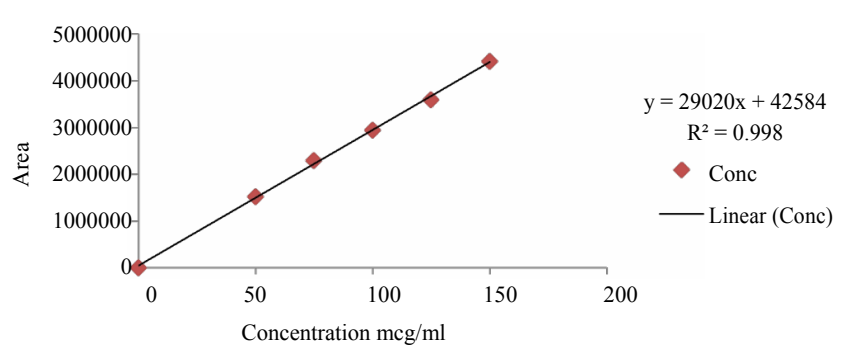

Figure 5: Linearity of Ethinyl estradiol.

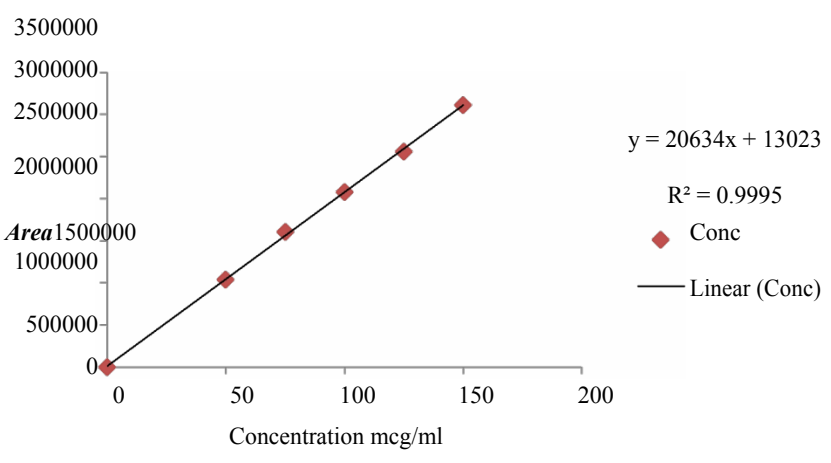

Figure 6: Linearity of Drospirenone.

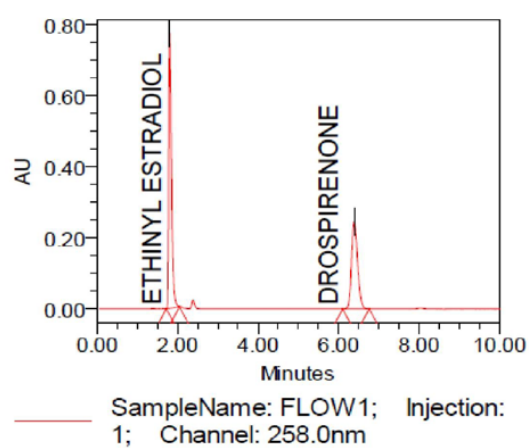

Figure 7: Chromatogram of ETH and DRO [Flow variation 1]

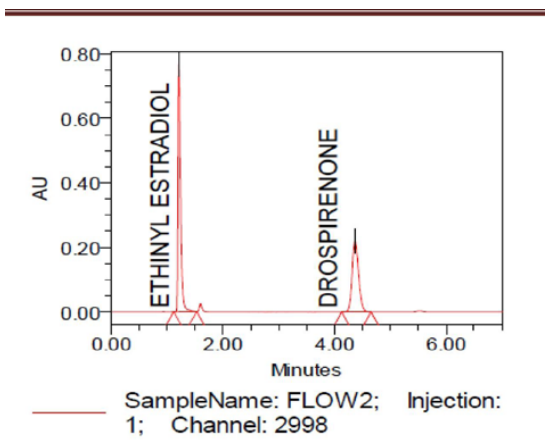

Figure 8: Chromatogram of ETH and DRO [Flow variation 2]

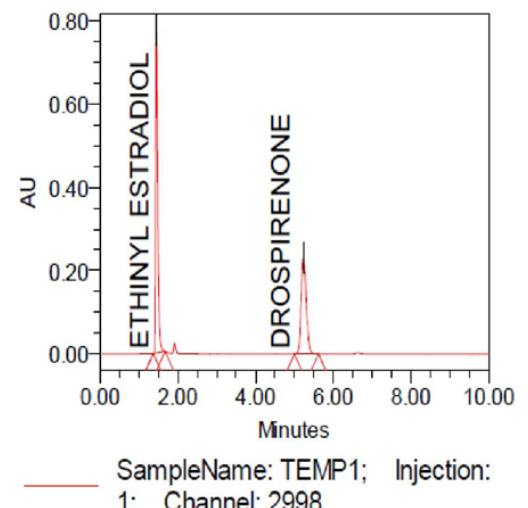

Figure 9: Chromatogram of ETH and DRO [Temperature variation 1].

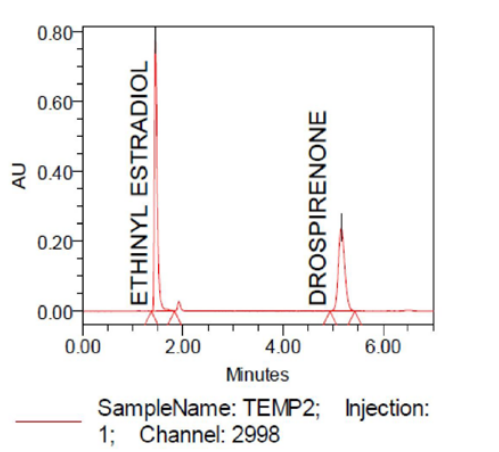

Figure 10: Chromatogram of ETH and DRO [Temperature variation 2].

\section{Accuracy}

The accuracy of the method was determined by recovery studies. The recovery studies were performed by standard addition method at $50 \%$ for six times, $100 \%$ for three times, $150 \%$ for six times and summarized in tables 5 and 6 .

\section{Limit of detection (LOD) and Limit of quantitation (LOQ)}

LOD is the ability of analytical method to detect the lowest concentration of the analyte. LOQ is the lowest concentration of the analyte with acceptable precision and accuracy. It can be calculated based on the signal to noise ratio. The LOD of ETH and DRO were $0.00026 \mathrm{ppm}$ and $0.0925 \mathrm{ppm}$. The LOQ of ETH and DRO were 0.00087 ppm and 0.308 ppm respectively.

\section{Robustness}

Robustness of the method was determined by making slight changes in the flow rate and column temperature. It was observed that there were no marked changes in the retention time and area of the chromatograms which demonstrated that the RP HPLC method developed was robust and data are summarized in table 1.

\section{Conclusion}

The Proposed RP-HPLC and UV-Spectrophotometric method were suitable techniques for simultaneous determination of Ethinyl estradiol and Drospirenone in combined dosage combinations without any interferences form each other and excipients. All the parameters 
Citation: Praveen C, Ranganath MK, Divakar P (2013) Method Development and Validation for Simultaneous Estimation of Ethinyl Estradiol and Drospirenone and Forced Degradation Behavior by HPLC in Combined Dosage Form. Pharmaceut Anal Acta 4: 231. doi:10.4172/21532435.1000231

for both the drugs had met the criteria of ICH guidelines for method validation. The low values of $\%$ RSD indicate the method is precise and accurate.

From the forced degradation studies it can be concluded that there is no other co-eluting peak with the main peaks and the method is specific for the estimation of Ethinyl estradiol and Drospirenone in presence of its degradation products and impurities. Result of validation parameter demonstrates that the analytical procedure is suitable for its intended purpose and meets the criteria defined in ICH Q2A/B.

\section{References}

1. Sweetman SC (2009) Ethinyl estradiol. Martindale: The complete drug reference. London Pharmaceutical Press: 2101.
2. Sweetman SC (2009) Drospirenone. In editor. Martindale: The complete drug reference. London Pharmaceutical Press: 2095.

3. Pradad G, Babu PS, Ramana MV (2011) Validated RP-HPLC method for the estimation of drospirenone in formulation. International Journal of Research in Pharmaceutical and Biomedical Sciences 2: 1341-1345.

4. Patel MG, Sagar GV (2012) Development and validation of analytical method for simultaneous estimation of ethinyl estradiol and cyproterone acetate in combined solid dosage form. International Journal of Universal Pharmacy and Life Sciences 2: 611-622.

5. Babu NB, Raju RR (2011) Simultaneous analysis and validation of Risperidone and Drospirenone drugs in pharmaceutical dosage form. International Journal of Research in Pharmaceutical and Biomedical Sciences 2: 1638-1642. 